\title{
液滴の生成と運動（その2）気液系*
}

ここでは，液体をノズルあるいは回転円盤などを使っ て, 気相中で徽粒化する場合に捕ける液滴の生成と運動 を取り上げる。

液体の微粒化は気液間の運動量交換，熱移動，物筫移 動の促進、円滑な連経然续あるいは塗装など、いろいろ の目的に用いられる手段であり，その重要性は最近でる 徽粒化に関する研究が数多く報告されていることからも 推察できよう。

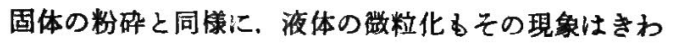
めて複雜であり，目的用途によって，液滴の生成過程す 異なっている。したがって，今後に残されている未明 な問題も少くないが、これまでの多くの研究者によって なされた研究成果を粉括的に述へ，スプレーに関する設 計, 操作条件, 生成液滴の粒径分布などを知る上での参 考に資したいと思ら。

\section{1. 液滴の生成週程}

液体が阙粒化してゆく過程はほほ三つの型に分類する ことができよ5。すなわち，(i) 線状液の切断，(ii) 薄 膜状液の分裂，(iii）液滴の衙撃的破裂である。

一般の微粒化では，以上の型が同時に混在していると 考えてよく，方法によってどれかの型が支配的となる。 なお，最後の項の衝俥的破裂とは高速気流中に心き出し

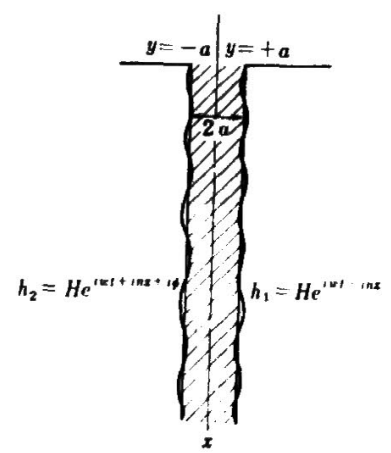

Fig. 1 Idealized fluid-sheet system ${ }^{\text {(3) }}$

*昭和 42 年 3 月 11 日受理

* Yoichi Takashima

果京工萧大学 原子如工学研究阶
た液滴がつぶれる上らな場合あるいははげしい振動を受 けて，破裂が起こるような場合であり，最も複雑な変形 運動をともな5。

（i）楾状波の切断 水道の蛇口などから系を引く 上5に水が流下し, 途中で, 切断が起こり夜滴が生成さ れる状況はしばしば見受けられることである。既に 1879 年 Lord Rayleigh ${ }^{29)}$ は理論的に非粘性液の線状からの 切断を解析した論文を呈出している。彼の理論では, 線 状液の形状が表面張力だけで支えられていると考え，そ の直径が局部的に增減するよ5な小さな振動が起こる場 合を想定している。結局，波長が直径 $D$ の 4.51 倍に相 当する振動か，最る生長し易く，生成液滴を $D_{p}$ とする と， $D_{p}=1.89 D$ となるような液滴ができ易い。その後， Weber ${ }^{40)}$ は液の粘性、気体の密度を考虑すると，最も 成長し易い振動の波長は長くなることを明かにし，例え ば，大気中での線状の水の流れでは $4.5 D$ ではなくむし ろ $6.5 \mathrm{D}$ に近い值を得ている。また高粘度液では線状液 の切断が起こり難く、微粒化はこの型によって生す゚るこ とが困難となる

（ii）膜状浓の分裂 Fan spray nozzle や Hollowcone nozzle から噴き出す液は膜状でノズルから大気中 に公かり，その薄くなった膜が振動によって破れて，無数 の夜滴となる。このような徽粒化の過程に関する研究は Squire ${ }^{33)}$, Hagerty $ら^{133}$ の膜の安定性の解析をはじめ,

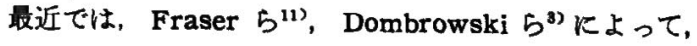
それぞれ，膜中に孔があき仏がることによる破裂や，粘 性の影䈏を考虑した解析などがある。

膜状流れの安定性について、ここでは Hagerty_らの 解析を籣単に述へよう。Fig. 1 にしめしたように, 膜の 厚みを $2 a$, 膜の移動方向を $x$, 膜に垂直な方向を $y$, 膜の平均移動速度を $V$ とし $, y=+a, y=-a$ の膜面に 小さい乱れが生じ，その角周波数を $\omega$, 初振幅を $H$, 波数を $n$ とする。今表面の連動を

$$
\left.\begin{array}{ll}
h_{1}=H e^{i \omega t+i n x} & (y=a) \\
h_{2}=H e^{i \omega t+\ln x+t \phi} & (y=-a)
\end{array}\right\}
$$

で表わされるとすると，液相 $(a \geq y \geq ー a)$ では速度ポ テンシャルは

$$
\Phi_{l}=(A \cosh n y+B \sinh n y) e^{l \omega t+i n x}+V x
$$

ここに 


$$
\left.\begin{array}{l}
A=\frac{i\left(\frac{\omega}{n}+V\right)\left(1-e^{i \phi}\right)}{2 \sinh n a} \cdot H \\
B=\frac{i\left(\frac{\omega}{n}+V\right)\left(1+e^{i \phi}\right)}{2 \cosh n a} H
\end{array}\right\}
$$

一方の気相 $(y>a)$ では

$$
\Phi_{o 1}=C e^{-n y+i n x+i \omega t}+V^{\prime} x
$$

$$
\text { ここに } \quad C=i H\left(V^{\prime}+\frac{\omega}{n}\right) e^{n a}
$$

他方の気相 $(y<-a)$ では

$$
\Phi_{R 2}=C e^{i \phi} \cdot e^{+n y+i n x+i \omega t}+V^{\prime} x
$$

また, Bernoulli の式より

$$
\frac{V^{2}}{2}=\frac{\partial \Phi}{\partial t}+\frac{q^{2}}{2}+\frac{\Delta p}{\rho} g_{c}
$$

ここに $q$ はある点における流速である。劝力と表面張 カの関保から

$$
\left.\begin{array}{l}
\Delta p_{l}-\Delta p_{g 1}=-\sigma \frac{\partial^{2} h_{1}}{\partial x^{2}} \\
\Delta p_{l}-\Delta p_{g 2}=+\sigma \frac{\partial^{2} h_{2}}{\partial x^{2}}
\end{array}\right\}
$$

以上の速度ポテンシャル, Bernoulli の式および表面 張力の式から, 次の二種の関係が得られる。

$$
\left.\begin{array}{l}
\phi=0 \\
\omega \doteqdot-n V \pm n \sqrt{\frac{n \sigma-V^{2} \rho_{g}}{\rho_{l} \tanh n a}}
\end{array}\right\} \text { 非対称波 }
$$

あるいは

$$
\left.\begin{array}{l}
\phi=\pi \\
\omega \doteqdot-n V \pm n \sqrt{\frac{n \sigma-V^{2} \rho_{0}}{\rho_{l} \operatorname{coth} n a}}
\end{array}\right\} \text { 对称波 }
$$

前者は膜の厚みが変らず，雄の運動に似た振動を起こ し、後者は膜幅が対称的に变動するような振動を起こす。

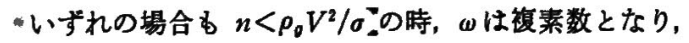
振動は成長するのて膜は不安定となる。なお， $\omega_{0}=n V$ とすると, 臨界周波数 $f_{\mathrm{c}}$ `は次のようになる。

$$
f_{0}=\frac{\omega_{0}}{2 \pi}=\frac{\rho_{g} V^{3}}{2 \pi \sigma}
$$

結局, 周波数 $f$ が $f_{c}$ 上り小の時, 膜は不安定となり, 乱れの成長速度 $\beta$ は

$$
\begin{aligned}
& \beta_{s}=n \sqrt{\frac{V^{2} \rho_{g}-n \sigma}{\rho_{l} \tanh n a}} \quad \text { (非対称波) } \\
& \beta_{D}=n \sqrt{\frac{V^{2} \rho_{g}-n \sigma}{\rho_{l} \operatorname{coth} n a}} \quad \text { (対称波) }
\end{aligned}
$$

となる。 $f<f_{c}$ の時, 1 サイクル前後の振幅をそれぞれ $y_{1}, y_{2}$ と怙くと

$$
\Delta=\ln \frac{y_{2}}{y_{1}}=\frac{\beta}{f}
$$

となり, $\Delta$ は正となる。今, $\Omega=f / f_{c}, W=V^{2} \rho_{\rho} a / a$ と おくと，

$$
\begin{aligned}
& \Delta_{s}=2 \pi \sqrt{\frac{\rho_{g}}{\rho_{l}} \frac{(1-\Omega)}{\tanh \Omega W}} \quad \text { (非対称波) } \\
& \Delta_{D}=2 \pi \sqrt{\frac{\rho_{g}}{\rho_{l}} \frac{(1-\Omega)}{\operatorname{coth} \Omega W}} \text { (対称波) }
\end{aligned}
$$

膜状流れの Weber 数 $W$ の值が $0.1,1.0$ に対し， 上式の関係を図示すると Fig. 2のようになる。

なお，

$$
\beta_{s}=\beta_{D} \operatorname{coth} n a
$$

となり， $\beta_{a}$ は $\beta_{D}$ より大きい。以上の関係から，液体の 薄谟状流れでは非対称振動による乱れから分裂が起こる ことが推定される。

一般に分裂が生するよ5な場合，na《1 と考えてよく， $\tanh n a \doteqdot n a$ となるので, 乱れの成長速度 $\beta_{8}$ の最大值

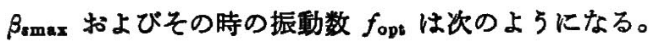

$$
\left.\begin{array}{l}
f_{\text {opt }}=\frac{1}{2} f_{c}=\frac{\rho_{g} V^{3}}{4 \pi \sigma} \\
\beta_{s \max } \doteqdot \frac{\rho_{g} V^{2}}{2 \sqrt{a \sigma \rho_{l}}}
\end{array}\right\}
$$

雪最も成長しやすい振動数 $f_{\mathrm{opr}}$ が膜の厚み $2 a$ に無関 係で，乙かす気体密度に関係することは着目に值す る。 Dombrowski ${ }^{4}{ }^{45}$ らは Fan spray nozzle による 微粒化に対し，上述の関係が成立することを確認してい る。なお，Hagerty らの解析では流れの広がりを考虑し

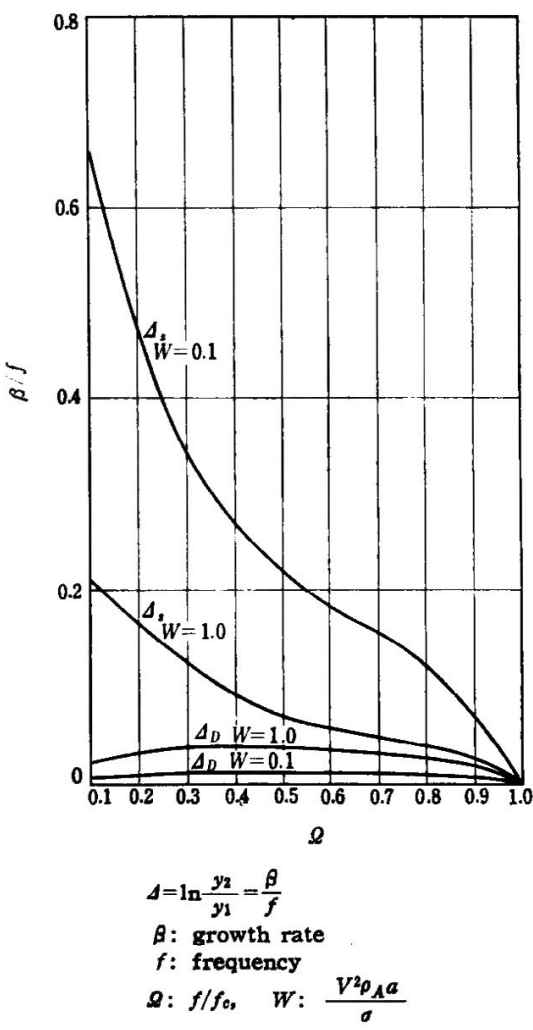

Fig. 2 Logarithmic decrement versus frequency ratio for sinuous and dilational waves ${ }^{13}$ ) 
ていないが，広がりがある場合でる解析結果を応用する ことができる。

Fig. 3 は Fan spray nozzle から薄膜状に噴出した 液の分裂する過程をしめしたるのである。 $x$ 軸上の流体 を考光，膜は一定速度を保ちながら，一定の角度で広がる とすると， $2 a x=k_{0}$ の関係が成立する。生ずる乱れは $f_{\mathrm{opt}}$ の振動数を持ち，その波長 $\lambda_{\mathrm{opt}}=V / f_{\mathrm{opt}}$ の半分すな わち $\lambda_{\text {opt }} / 2$ の幅の板状液に切断されると考える。この板 状液は表面張力のため, 直ちに棒状液となるとする。切 断時の膜の厚みを $2 a^{*}$, 棒状液の半径を $r_{\iota}$ とおくと,

$$
r_{\iota}=\left(\frac{\lambda_{\mathrm{opt}} a^{*}}{\pi}\right)^{1 / 2}
$$

もし棒状液の切断が Rayleigh の理論に従らとする と, それから生成される液滴 $d$ は $d=3.78 r$ となるか 5

$$
d \doteqdot 3.78\left(\frac{\lambda_{\mathrm{op}} a^{*}}{\pi}\right)^{1 / 2}
$$

が得られる。ここで $a^{*}$ を推定することができれば，生 成液滴の大きさも推定可能となる。

Weber $^{40)}$, Fraser $^{10)}$ らの実験によると乱れの成長度 $E$ を

$$
E=\int_{0}^{t} \beta d t=\ln \frac{y_{t}}{y_{0}}
$$

と打くと, 破断が起こるまでの成長度 $E^{*}$ はノズルが与 えられるえ, 液流速 $V$, 気体密度 $\rho_{g}$ に無関係に一定であ るといわれる。したがって, $x=V t$ すなわち, $t=k_{0} / 2 a V$ の関伱から，

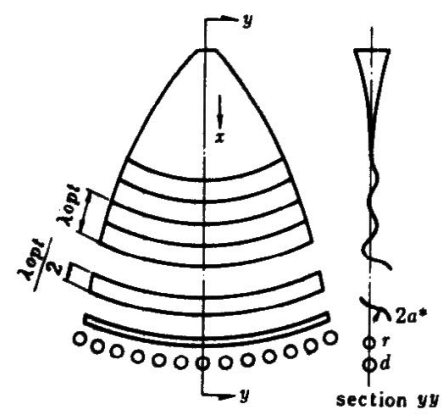

Fig. 3 A model of break up by sinuous wave (from Ref. (10))

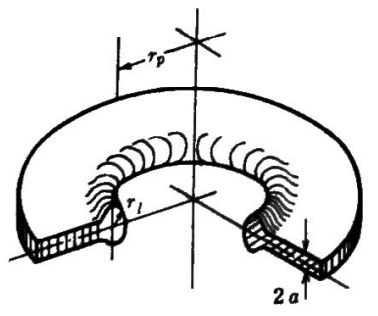

Fig. 4 Perforation in a liquid sheet (from Ref. (10))

$$
a^{* 1 / 2}=\frac{1}{6} E^{\left(\rho_{l} V k_{0}\right)^{1 / 3}}\left(\rho_{l} \sigma\right)^{1 / 6}
$$

さらに

$$
\begin{aligned}
d & =\frac{1.26}{E^{* 1 / 3}}\left(\frac{\sigma k_{0}}{\rho_{l} V^{2}}\right)^{1 / 3}\left(\frac{\rho_{l}}{\rho_{0}}\right)^{1 / 6} \\
& =\text { const }\left(\frac{\sigma k_{0}}{C^{2} \Delta p}\right)^{1 / 3}\left(\frac{\rho_{l}}{\rho_{0}}\right)^{1 / 6}
\end{aligned}
$$

ここに $\Delta p$ はノズルに液を供給する駆動圧力で，Cはノ ズルの流出係数である。この関係は Hollow-cone nozzle に対しても成立し，実験式をまとめる場合に重要な意味 を持つ。最近, 気体の密度 $\rho_{0}$ がはたして生成液滴の平均 径 $d$ に対し， $d \infty \rho_{0}{ }^{-1 / 6}$ となる上うな影響があるかどう か Fraser ${ }^{111}$ らにより検討されている。すなわち Fraser らは絶対圧力 $20 \mathrm{~mm} \mathrm{Hg} 760 \mathrm{~mm} \mathrm{Hg}$ の容器内で spray を行なって，写真撮影による薄膜液の破裂を調べる一方， 生成液滴の比表面積平均径の大きさと, $\rho_{0}$ の関係を調へ ている。

その結果, 䄪 $200 \mathrm{~mm} \mathrm{Hg}$ 以上の範囲ではほぼ $d \operatorname{cs} \rho_{0}^{-1 / 6}$ が成立するが，圧力が低下すると， $d$ の值は急激に增加 乙, 約 30\%ぐらい過大となり, 更に圧力が低下すると, dはむしろ減少する傾向にあることなどが認められた。 一方，低圧での薄膜状液の分裂を観測した結果によると， 膜に小滴などの衝突によって孔があき，その孔が広がる ことにより液滴が生ずる過程を認めている。これは脱が ス, 脱塩された純水を用いてもはとんど同様に起こるこ とから，不純物の混入などによる膜切れではないかと考 えられている。

Fig.4に薄膜に孔があいた後の広がりの模様をしめす。 半径方向の広がり速度を $e$ とすると, 表面張力, 運動量 変化の関係から

$$
4 \pi r_{p} \sigma=\frac{\delta}{\delta t} \rho_{l \pi} r_{p}^{2} \cdot 2 a e
$$

また $e=\delta r_{p} / \delta t$ と見なされるから，最初の孔がきわめ て小さいとすると

$$
e \doteqdot \sqrt{\frac{\sigma}{a \rho_{l}}}=\sqrt{\frac{2 \sigma x}{\rho_{l} \cdot k_{0}}}
$$

となる。孔の成長速度は孔の大きさに無関係である。e の值は二重露出法によって写真から測定され, 理論式と よく合5といわれているが，この研究に関しては他に $\operatorname{Ranz}^{28)}$ の報告がある。

なお，Twin nozzles による薄膜の生成およびその分 裂に関する研究行, 38) 興味ある問題を含んでいるが，こ こでは省略する。

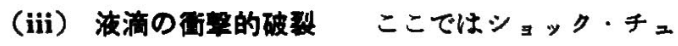
一プの中で, ェフブラストによる液滴の破裂に関する Hanson ${ }^{14)}$ らの研究結果扰よび超音速気流中での液滴の 微粒化を行なった Bitron"2)の報告について简単に述へ る。 
Fig. 5 Kエフブラストによる水滴の破裂の模様をしめ す。図のように流れに直面している部分がまず押しつふ され，更に凹んで，Cup 状となり薄膜となってつぶされ る。一方, 流れに垂直な滴の大円周辺は外側の異常低圧 と相まって，大きな輪を形成する。Fig. 6 は Silicone oil 100 の液滴の破裂であるが，そのつぶれ方は更に複 雑である。

Tables 1, 2 にエアブラストによって液滴が破れる限界 気流速度 $V_{c}$ と使用した液の粘性, 表面張力の関係をし めす。なお，1949年 Hinze ${ }^{17)}$ は既に Merrington ${ }^{24)}$ ら の液滴落下実験で, 液滴の破裂は元の球からの变形か， ほぼその半径に等しい時に生じていることに着目し, 粘 性パラメータ $K=\mu^{2} / \rho_{l} \sigma r$ が1より小の時と大の時にわ けて臨界 Weber 数, Wcrit $\left(=\rho_{g} V_{c}^{2} r / \sigma\right)$ が次の関係と なることを述てている。

$$
\begin{array}{lll}
K \ll 1 & \text { の時 } & W_{\text {erit }}=6 \\
K>1 & \text { の時 } & W_{\text {erit }}=10
\end{array}
$$

この関係は微粒化の限界を知るための貴重な目安とな っている。この Hinze の式と, Hanson の得た Table 2 のデータを比較すると, 落下液滴の破裂とエアブラスト による破裂の相異ばかりではなく, 実際, Wcritは液滴 の大きさなどによっても異なり，むしろ $R e\left(=2 V_{\mathrm{c}} r / \nu_{q}\right)$ との積が一定に近いように思われる。いつれにしろ、今 後の詳細な実験結果を期待したい所であるが, Hinze の 述へている簡単な関保はある程度, 修正されることにな るであろう。

高速気流による液の微粒化については抜山、棚沢 ${ }^{27)} に$ よる著名な実験式がある。

$$
d_{s}=\frac{585}{V^{\prime}-V}\left(\frac{\sigma}{\rho_{l}}\right)^{0.5}+597\left(\frac{\mu_{l}}{\sqrt{\rho_{l} \sigma}}\right)^{0.45}\left(\frac{1000 Q_{l}}{Q_{g}}\right)^{1.5}
$$

ここに $d_{\mathrm{s}}$ は比表面積平均粒径 $(\mu), V^{\prime}, V$ はそれぞ れ気体, 液体の速度 $(\mathrm{m} / \mathrm{sec}) 、 Q_{l}, Q_{0}$ はそれぞれ液体, 気体の流量 (cc/sec) である。この式は次元的には不健 全にもかかわらず，実際とよく合らことが，他の実験者 たち2.23)にす認められている。特に Bitron ${ }^{2)}$ は超音速気 流（マッ八数 2 以下）に対しても適応できると述へてい る。

以上,三つの型に関する液滴の生成について述へたが, 主として，ノズルに関係した微粒化を対象としているの で，次に回転盤による微粒化にふれてみよう。

\section{2. 回枟盤による微柆化}

この方法のすぐれた点は比較的均一な大きさの液滴が 得られること,ノズルの場合にはつまったりする恐れの ある液体です取り扱 らことができることである。ただし， 流量に制限があって, その制限以上では生成液滴は大き
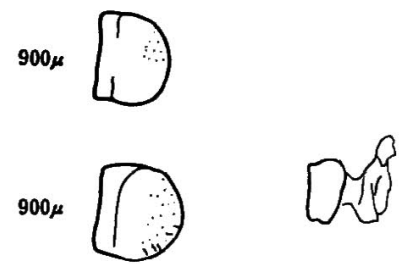

$273 \mu$
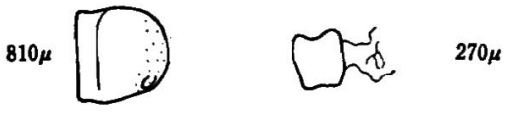

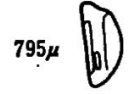

Fig. 5

Breakup of water drops by $110 \mathrm{ft} / \mathrm{sec}$ air blast

(from Ref. (14))
Fig. 6

Breakup of drops of 100 cstk silicone oil by $119 \mathrm{ft} / \mathrm{sec}$ air blast (from Ref. (14))

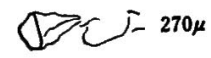

Table 1 Fluid properties (from Ref. (14))

\begin{tabular}{cccc} 
Liquid & $\nu$ cstk & $\sigma$ dyne $/ \mathbf{c m}$ & $\rho \mathbf{g} / \mathbf{c c}$ \\
\hline Silicone oil & 10 & 20.14 & 0.940 \\
$" \prime \prime "$ & 50 & 20.18 & 0.960 \\
$" \prime \prime$ & 100 & 20.92 & 0.970 \\
Water & 0.892 & 71.97 & 0.998 \\
Methyl alcohol & 0.696 & 22.2 & 0.787 \\
\hline
\end{tabular}

\begin{tabular}{|c|c|c|c|c|c|c|}
\hline \multicolumn{2}{|c|}{ Liquid } & $V_{c} \mathrm{ft} / \mathrm{sec}$ & $D_{\mu}$ & $W$ erit & $R e$ & $(W R e)$ crit \\
\hline \multirow[t]{4}{*}{ Silicone } & oil 10 & 73.5 & 426 & 6.62 & 592 & 3,920 \\
\hline & & 93.0 & 285 & 7.18 & 501 & 3,600 \\
\hline & & 121.3 & 180 & 7.93 & 406 & 3,220 \\
\hline & & 148.5 & 117 & 7.94 & 317 & 2,520 \\
\hline \multirow[t]{4}{*}{$"$} & " 50 & 83.5 & 531 & 10.4 & 841 & 8,720 \\
\hline & & 122.0 & 273 & 11.8 & 611 & 7,220 \\
\hline & & 148.0 & 210 & 13.5 & 561 & 7,550 \\
\hline & & 199.2 & 126 & 15.4 & 444 & 6,850 \\
\hline \multirow[t]{6}{*}{$"$} & $" 100$ & 93.7 & 540 & 13.1 & 946 & 12,380 \\
\hline & & 122.0 & 338 & 14.3 & 749 & 10,730 \\
\hline & & 148.5 & 239 & 15.5 & 649 & 10,100 \\
\hline & & 149.3 & 250 & 16.2 & 668 & 10,850 \\
\hline & & 199.3 & 185 & 22.6 & 650 & 14,700 \\
\hline & & 228.5 & 150 & 23.8 & 577 & 13,740 \\
\hline \multirow{3}{*}{\multicolumn{2}{|c|}{ Water }} & 121.3 & 391 & 4.79 & 864 & 4,140 \\
\hline & & 198.8 & 180 & 6.37 & 632 & 4,030 \\
\hline & & 282.0 & 94.5 & 7.14 & 446 & 3,180 \\
\hline \multirow{2}{*}{\multicolumn{2}{|c|}{ Methyl alcohol }} & 74.4 & 471 & 6.76 & 661 & 4,470 \\
\hline & & 121.3 & 186 & 7.45 & 415 & 3,090 \\
\hline
\end{tabular}

Table 2 Representative values of $W_{\text {critt }}$. $\& \operatorname{Re}$ (from Ref. (14))

くまた不均一となり，わさわさこの方法を採用した意 義も薄れてしまう。

Hinze ${ }^{18)}$ らは Fig. 7 にしめすような回転キャッブ型 スブレーに関する研究を行ない, この方法による液滴の 生成過程を明らかにしているので，その内容を簡単に述 


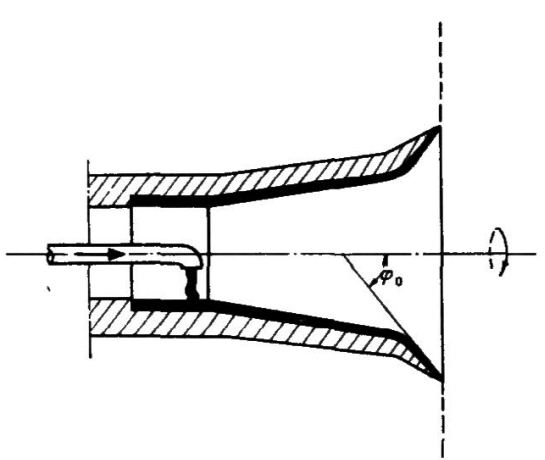

Fig. 7 A rotating cup for atomization ${ }^{\text {(1) }}$

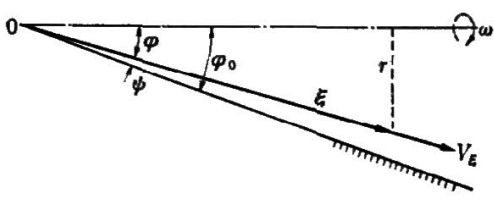

Fig. 8 A velocity component in layer of liquid within cup

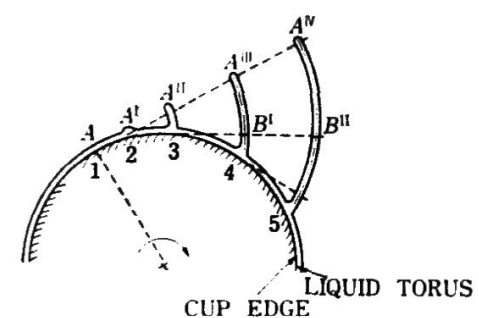

Fig. 9 Geometrical development of liquid ligaments from a liquid torus (from Ref. (18))

ひる。Fig. 8 にしめす記号に従 5 と， $\xi$ 方向の流速 $v_{\xi}$, 流量 $Q$ は次のよ5になる。

$$
\begin{aligned}
& v_{\xi}=\frac{\rho \omega^{2}}{\mu} \sin ^{2} \varphi_{0}\left(\xi_{1}^{3} \psi_{1} \psi-\xi^{2} \frac{\phi^{2}}{2}\right) \\
& Q=\int_{0}^{\omega_{1}} 2 \pi r \xi d \psi v_{\xi}=\frac{2 \pi \rho \omega^{2} \xi_{1}^{5} \sin ^{3} \varphi_{0} \cdot \psi_{1}^{3}}{3 \mu}
\end{aligned}
$$

この関係が成立するのは，液が層流をなし，回転方向 に滑りがない時であることはいうまですないであろう。 次に出口の流れの厚み $\delta=\xi_{1} \phi_{1}$, 出口周辺直径 $D=$ $2 \xi_{1} \sin \varphi_{0}$ とすると

$$
\delta=\left(\frac{6 \mu Q}{\pi \omega^{2}} \frac{D^{2} \sin \varphi_{0}}{{ }^{2}}\right)^{1 / 3}
$$

Fig. 9 に液がキャップを離脱する状況をしめす。小流 量の場合は周辺に細い液の輪 (liquid torus) ができ， そこで，最る成長しやすい振動に相当する波畏入の間隔 ことに棒状液が弧を画いてとび出す。Hinze は実殹およ び次元解析の結果, 棒状液の本数を $Z$ として,

$$
Z=\frac{\pi D}{\lambda}=0.215\left(\frac{\rho_{l \omega^{2} D^{8}}}{\sigma}\right)^{5 / 12}\left(\frac{\rho_{l \sigma} D}{\mu^{2}}\right)^{1 / 6}
$$

という関係を導出している。限界流量 $\boldsymbol{Q}_{\boldsymbol{c}}$ 以下で上の式 は成立するが， $Q_{c}$ Kついては次の関係を得ている。

$$
\frac{\rho Q_{c}{ }^{2}}{\sigma D^{3}} \cdot\left(\frac{\rho \omega^{2} D^{3}}{\sigma}\right)^{0.60}\left(\frac{\mu^{2}}{\rho_{l} \sigma D}\right)^{0.167}=1.77
$$

なお， torus からとび出した線状液の切断により, 液 滴が生成されるが，その大きさを比表面積平均径 $d_{s}$ で しめすと,

$$
\frac{d_{s}}{D}=0.41\left(\frac{Q}{\omega D^{3}}\right)^{0.6}\left(\frac{\mu D}{\rho_{l} Q}\right)^{0.2}\left(\frac{\sigma D^{3}}{\rho_{l} Q^{2}}\right)^{0.1}
$$

この関係は回転円盤に対し得られた実験式である ${ }^{9.12) 。 ~}$

また，粒径分布の分散の程度は後で述べる $\sigma_{l}$ でしめ すと， $\sigma_{l} \doteqdot 0.1$ であり，ノズルによるスプレーから得ら れる液滴の場合は $\sigma_{l} \doteqdot 0.8$ である。回転盤により得られ る液滴がはるかに均一となっていることはこのことから も明らかであるが，限界流量を越すと，ノズルの場合と 同じになる。

\section{3. 液滴の粒径分布}

以上，液滴の生成過程について述べてきたように，現 象が複雑な割合に汇研究すある程度進んでいるので，微 粒化を試みる場合，大きな支障はないと思われる。一方 生成液滴の粒径分布に関しては，分布が生ずる確率過程 が明らかでないばかりでなく、スブレーの方法によって も違ってくるために，決定的なことは何す得られていな いといってよいであろう。ただ，経験的に分布関数とし て実際々よく適合できるとみなされている著名な式が数 種用いられており，実用上，どの式を用いてもあまり大 きな差異はなく，現在ですきわめてあいまいに取り扱わ れている。ここでは特によく用いられている三つの分布 式についての相互関係を明らかにしてみよら。

（i）対数正規分布 ${ }^{1,7,26,34)} こ の$ 分布は確率過程が 判然としている。たとえば，液片が十分多数の振動を受 け，ずたずたにちきれてゆく場合を想定し，1回の波を 受けるたびにちきれる確率は大きいかけらす小さいかけ らも，大きさの差別なく同じであると，得られる液滴の 粒径分布は対数正規に近つく。これは1941 年, Kolmogoroff ${ }^{211}$ Kより数学的にも明らかにされ，確率が $1 / 2$ に 派い程，分布は仏く，0または 1 に近いほど㹟い。その 分布式は

$$
\left\{\begin{array}{l}
\frac{d n}{N d \ln x}=\frac{1}{\sqrt{2 \pi} \sigma_{l}} \exp -\frac{(\ln x / \bar{x})^{2}}{2 \sigma_{l}^{2}} \\
\frac{d v}{V d \ln x}=\frac{1}{\sqrt{2 \pi} \sigma_{l}} \exp -\frac{(\ln x / \tilde{x})^{2}}{2 \sigma_{l}^{2}} \\
\tilde{x}=\bar{x} \cdot \exp 3 \sigma_{l}^{2}
\end{array}\right.
$$

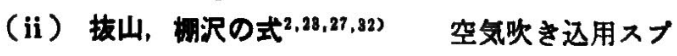


レーノズルから得られた液滴の分布を抜山，棚沢らが検 討した結果. 以下の式により表示している。確率過程の物 理的意味は明らかでないが，現在でもよく用いられる。

$$
\left\{\begin{array}{l}
\frac{d n}{N d \ln x} \\
=B x^{3} e^{-b x^{a}} \\
\quad=\frac{3\left(\alpha_{n} / e\right)^{\alpha_{n}}}{\Gamma\left(\alpha_{n}+1\right)} \exp \alpha_{n}\left\{1-\left(\frac{x}{\bar{x}^{\prime}}\right)^{3 / \alpha_{n}}+\frac{3}{\alpha_{n}} \ln \frac{x}{\bar{x}^{\prime}}\right\} \\
\quad \frac{3}{\sqrt{2 \pi \alpha_{n}}} \exp \alpha_{n}\left\{1-\left(-\frac{x}{\bar{x}^{\prime}}\right)^{3 / \alpha_{n}}+\frac{3}{\alpha_{n}} \ln \frac{x}{\tilde{x}^{\prime}}\right\} \\
\frac{d v}{V d \ln x} \div \frac{6}{\sqrt{2 \pi \alpha_{v}}} \exp \alpha_{v}\left\{1-\left(\frac{x}{\tilde{\tilde{x}}^{\prime}}\right)^{3 / \alpha_{v}}+\frac{3}{\alpha_{v}} \ln \frac{x}{\tilde{x}^{\prime}}\right\} \\
\alpha_{v}=2 \alpha_{n}, \quad \tilde{x}^{\prime}=2^{\alpha_{n} / 3} \cdot \bar{x}^{\prime}
\end{array}\right.
$$

(iii) Rosin-Rammler の式 ${ }^{15.30)}$ これも確率過程 の意味がはっきりしないが、粉体の場合と同様に, 液滴 の分布にも用いられる。

$$
\left\{\begin{array}{l}
\frac{d n}{N d \ln x} \\
=\frac{3}{1-\delta_{n}} \frac{\left(\delta_{n} / e\right)^{\delta_{n}}}{\Gamma\left(1+\delta_{n}\right)} \exp \left\{1+\delta \ln -\frac{x}{\bar{x}^{\prime \prime}}-\left(\frac{x}{\bar{x}^{\prime \prime}}\right)^{\delta}\right\} \\
\frac{d v}{V d \ln x}=\frac{\delta}{e} \exp \left\{1+\delta \ln \frac{x}{\tilde{x}^{\prime \prime}}-\left(\frac{x}{\tilde{x}^{\prime \prime}}\right)^{\delta}\right. \\
\delta_{n}=\frac{\delta-3}{\delta}, \quad \tilde{x}^{\prime \prime}=\left(\frac{\delta}{\delta-3}\right)^{1 / \delta} \bar{x}^{\prime \prime}
\end{array}\right.
$$

以上の三つの表示式で, $N$ は液滴全個数, $d n$ は滴の 大きさが $x$ と $x+d x$ の間にある個数, $V$ は滴の全容 積,$d v$ は $x$ と $x+d x$ の間婂ある大きさの滴がしめる容 積， $\bar{x} ， \bar{x}^{\prime} ， \bar{x}^{\prime \prime}$ はそれぞれの $d n / d \ln x(=x d n / d x)$ が最 大の時の $x$ の值であり, $\tilde{x}, \tilde{x}^{\prime}, \tilde{x}^{\prime \prime}$ はそれぞれの $d v / d \ln x$ が最大となる $x$ の值である。

3 者を比較するため, $(d n / d \ln x)_{\max }$ が相等しく， $\bar{x}=\bar{x}^{\prime}=\bar{x}^{\prime \prime}$ と扰くと，扔のおのの分散に関係ある因子 $\sigma_{l}, \alpha_{n}, \delta_{n}$ は次のよ5になる。

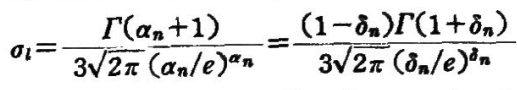

また， $(d v / d \ln x)_{\max }$ が相等しく， $\tilde{x}=\tilde{x}^{\prime}=\tilde{x}^{\prime \prime}$ とおくく 飞

$$
\sigma_{l}=\frac{\Gamma\left(\alpha_{l}+1\right)}{6 \sqrt{2 \pi}\left(\alpha_{l} / e\right)^{\alpha_{l}}}=\frac{e}{\sqrt{2 \pi}}-\frac{1}{\delta}
$$

これらの関係は Fig.10のよろになる。なお，上の 2 式は，同時に成立しないことK注意を要する。 $\alpha_{l}, \alpha_{n}$; $\boldsymbol{\delta}, \boldsymbol{\delta}_{n}$ の相互関係は（ii）（iii）としめす通りである。

この上5に $\sigma, \alpha, \delta$ の関係から実剆値と此較して，と の関数形が最も適合するかを調べることができる。次に 分布式の健全性にふれてみよう。

Rosin-Rammler の式では $\delta>3$ でなければならない。 すなわち $\sigma_{l}<0.36$ 火注相当する分布でなければなら ないことを意味し，かなり均一な液滴の分布の場合に限 られる。このよろな均一な分布の場合は，分布関数がどれ

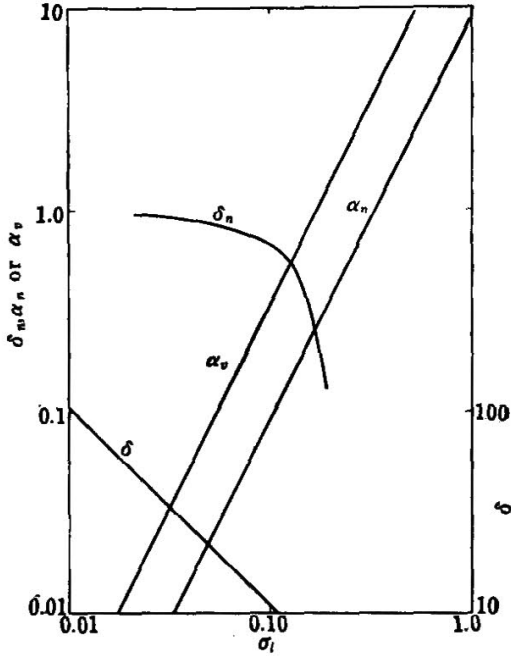

$$
\begin{aligned}
\sigma_{l} & =\frac{\Gamma\left(\alpha_{n}+1\right)}{3 \sqrt{2 \pi}\left(\alpha_{n} / e\right)^{\alpha_{n}}} \div \frac{\sqrt{\alpha_{n}}}{3} \\
& =\frac{\left(1-\delta_{n}\right) \Gamma\left(1+\delta_{n}\right)}{3 \sqrt{2 \pi}\left(\delta_{n} / e\right)^{\delta_{n}}}
\end{aligned}
$$

for $\bar{x}=\vec{x}^{\prime}=\bar{x}^{\prime \prime}$, the same value of $(d n / d, \ln x)_{\max }$

$$
\begin{aligned}
\sigma_{l} & =\frac{\Gamma\left(\alpha_{v}+1\right)}{6 \sqrt{2 \pi}\left(\alpha_{v} / \varepsilon\right)^{\alpha_{v}}} \div \frac{\sqrt{\alpha_{v}}}{6} \\
& =\frac{e}{\sqrt{2} \pi}-\frac{1}{\delta}
\end{aligned}
$$

for $\tilde{x}=\tilde{x}^{\prime}=\tilde{x}^{\prime \prime}$, the same velue of $(d v / d \ln x)_{\max }$

Fig. 10 The relation between $\sigma_{l}, \alpha_{n}, \delta_{n}$ or $\sigma_{l}, \alpha_{v}, \delta$

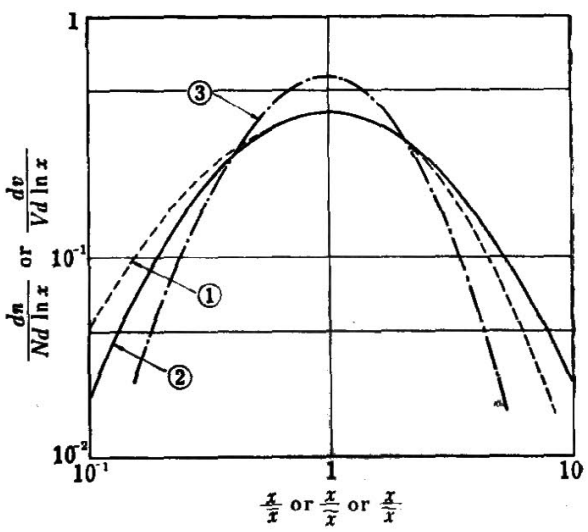

(2) N.T. distribution of $d n / N d \ln x$ to $x / \bar{x}^{\prime}$

(2) $\log$ normal distribution of either $d n / N d \ln x$ to $x / \bar{x}$ or $d v / V d \ln ^{\prime} x$ to $x / \tilde{x}$

(3) N.T. distribution of $d v / V d \ln x$ to $x / \tilde{x}^{\prime}$, $\tilde{x}=20 \bar{x}, \quad \bar{x}^{\prime}=9 \bar{x}, \bar{x}=\bar{x}^{\prime}$

Fig. 11 Comparison between log normal distribution and Nukiyama-Tanazawa's equation

であっても, 種々の平均値を求める場合飞あまり盖は生 じない。したがって, 使用価値はあまりないと思われる。

(i)，(ii)の諸式を $\bar{x}=\bar{x}^{\prime},(d n / d \ln x)_{\max }=0.4 N$ とし, したがって $\sigma_{l}=1.0, \alpha_{n} \doteqdot 9$ の場合を比較すると, Fig. 11 のような関保が得られる。個数分布を小さい粒径で比較 
すると，(ii）の式では相対的に個数が多くなり，このこ とは小さい液片がむしろ破れ易いという確率過程が含ま れることを意味する。その意味では（ii）の式す多少の 矛盾を含んでいるが，その差は容積で考学ると無視でき る。一般に液滴群には最大，最小径が存在するので，実 際の分布も，(i)，(ii) の諸式に比へ，両端で激減する のが当然である。そのため，大きい方の分布は図から明 らかなよらに，(ii) 式がよりよい近似をしめすことが多 W。

しかし、以上にあげた三つの分布式はいづれも最大径， 最小径の存在を考虑していないので，別に補正すること を考える必要がある。Hollow-cone nozzle の実験で， 特に最大粒径に近い所の分布を調べた例い(では, Hinze がしめしたように $W$ crit〜10 として求めた $x_{M}$ がほほ 最大径となっておりり， $x_{M}$ は $\bar{x}$ の約 30 倍である。 $x \leq 20 \bar{x}$ ではほとんど，対数正規分布となっており， $x \geq 20 \bar{x} て ゙$
分布は激減し正規分布からはずれることが認められる。

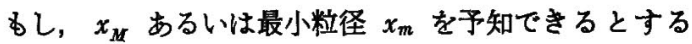
と, 最す簡単な補正として

$$
X=\frac{x-x_{m}}{x_{M}^{n}-x^{n}} x_{M}^{n}
$$

と打き, $x$ の代わりに $X$ を用いると, 対数正規分布は多 くの場合よく適合する ${ }^{26)}$ 。一般に $x_{m} \ll \bar{x} \ll x_{M}$ であるの で広い範围で $X \doteqdot x$ となる。多くの場合， $x_{m}$ は無視で きるか， wax のスプレーなどでは微粒化の進行不十分 の内に冷却固化が起こるので $x_{m}$ の補正が必要となる。 この補正による対数正規分布式が最も妥当と提唱したの は Evans \& Mugele であり，筆者もその意見に同意す る。

なお，紙面の都合で省略したが，ノズルによる微粒

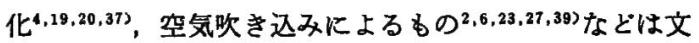
献を参照されたい。

\section{Nomenclature}

$a$ : half width of fluid sheet, $\quad d$ : drop diameter, $\quad e$ : growth rate of perforation, $f_{c}$ : lowest stable frequency, $h$ : disturbance on surface, $n$ : wave number of disturbing wave, or number of drops, $p$ : pressure, $r$ : radius of liquid filament, $x$ : distance in the direction of the liquid flow or drop size, $y$ : distance perpendicular to sheet from center line, $t:$ time, $D:$ diameter of a spinning disc, $E$ : growth of disturbance, $\quad H$ : initial amplitude of disturbing wave, $Q$ : flow rate, $\quad V$ : mean velocity of liquid sheet, $V^{\prime}$ : mean velocity of surrounding gas, $W$ : Weber's number, $\quad Z$ : Number of liquid ligaments from a rotating disc, $\beta$ : growth rate of disturbance, $\lambda$ : wave length, $\rho$ : density, $\sigma$ : surface tension, $\omega$ : circular frequency of disturbing wave, $\phi$ : phase angle between disturbances on upper and lower surfaces, $\phi$ : velocity potential, $\mu$ : viscosity, $\xi$ : distance in the direction of liquid flow in a cup

\section{References}

1) Binark, H. \& Ranz, W.E.: I.E. C., 51, 701 (1959)

2) Bitron, M.D.: I. E. C., 47, 23 (1955)

3) Dombrowski, N., Hasson, D. \& Ward, D.E. : Chem. Eng. Sci, 12, 35 (1960)

4) Dombrowski, N. \& Hooper, P.C. : Chem. Eng. Sci., 17, 291 (1962)

5) Dombrowski, N. \& Johns, W.R.: Chem. Eng. Sci, 18, 203 (1963)

6) Dorman, R.G. : Brit. J. Appl. Phys., 3, 189 (1952)

7) Epstein, B. : I. E. C., 40, 2289 (1948)

8) Fogler, B. B. \& Kleinschmidt, R. V.: I. E. C., 30, 1372 (1938)

9) Fraser, R.P., Eisenklam, P. \& Dombrowski, N. : Brit. Chem. Eng., Aug. 415, Sept. 497, Oct. 536, Nov. 611 (1957)

10) Fraeer, R.P, et al.: A. 1.Ch. E. J. 8, 672 (1962)

11) Fraser, R.P., Dombrowski, N. \& Routley, J. H.: Chem. Eng. Sci., 18, 339 (1963)

12) Friedman, S. J., et al.: Chem. Eng. Prog., 48, 181 (1952)

13) Hagerty, W. W. \& Shea, J. F. : J. Appl. Mech., 22, 509 (1955)

14) Hanson, A.R., Domich, E.G. \& ADams, H.S.: Physics of Fluids, 6, 1070 (1963)

15) Hasson, D. \& Mizrahi, J.: Trans. Inst. Chem. Eng., 38, 415 (1961)

16) Hasson, D. \& Peck, R.E.: A. t. Ch. E. J., 10, 752 (1964)

17) Hinze, J. O.: Appl. Sci. Res., A 1, 263, 273 (1949)

18) Hinze, J. O. \& Milborn, H.: J. Appl. Mech., 17, 145 (1950)

19) Houghton, H. G.: J.H. Perry's Chem. Eng. Handbook, Fourth Ed., 18-61 (1963)

20) Kobayashi, K.: J. Japan Soc. Mech. Eng., 17, 107, 112, 114
(1951)

21) Kolmogoroff, A. N.: Compt. rend. acad. Sci, URSS, 31, 99 (1941)

22) Lee, D. W.: N. A.C. A. report No. 425 (1932)

23) Lewis, H.C., et al. : I. E. C. 40, 67 (1948)

24) Merrington, A.C. \& Richardson, E. G. : Proc. Phys. Soc. (London), 59, 1 (1947)

25) Meyer, W.E. \& Ranz, W.E. : Encyclopedia of Chemical Technology, 12, 703 (1954)

26) Mugele, R. A. \& Evans, H.D.: I. E. C., 43, 1317 (1951)

27) Nukiyama, S. \& Tanazawa, Y.: Trans. Japan Soc. Mech. Eng., 4, 86, 138 (1938); 5, 63, 68 (1939); 8, 2-7 (1940)

28) Ranz, W.E.: J. Appl. Phys., 30, 1950 (1959)

29) Rayleigh, Lord: Proc, Roy. Soc., 29, 71 (1879)

30) Rosin, P. \& Rammler, E.: J. Inst. Fuel, 7, 29 (1933)

31) Rossum, J. J. : Chem. Eng. Sci., 11, 35 (1959)

32) Sagai, T. \& Sugiyama, Y. : Chem. Eng., Japan, 29, 14 (1965)

33) Squire, H. B. : Brit. J. Appl. Phys., 4, 167 (1953)

34) Takashima, Y.: Preprints of the 4 th Symposium by Soc. Chem. Eng. Japan, 88 (1965)

35) Tanazawa, Y.: Trans. Japan Soc. Mech. Eng., 8, 2-18 (1940)

36) Tanazawa, Y., et al.: Trans. Japan Soc. Mech. Eng., 1, 2-5 (1941)

37) Tate, R.W. \& Marshall, W. R. Jr.: Chem. Eng. Prog., 48, 226 (1953)

38) Taylor, G.: Proc. Roy. Soc., A 259. 1 (1960)

39) Ullrich, J.: Glastechn. Ber., 32 Jahrg., Heft 3, 121 (1959)

40) Weber, C.: Z. angew. Math. \& Mech., Bd 11, Heft 2, 136 (1931) 